\section{ECONOMICS}

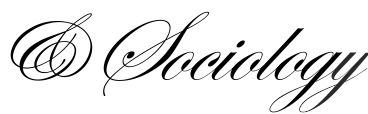

Received: April, 2017

1st Revision: September, 2017

Accepted: November, 2017

DOI: $10.14254 / 2071-$

789X.2017/10-4/11
Dheera-aumpon, S. (2017). Humane Orientation and Corruption in Bank

Lending. Economics and Sociology, 10(4), 137-150. doi:10.14254/2071-

789X.2017/10-4/11

\title{
HUMANE ORIENTATION AND CORRUPTION IN BANK LENDING
}

\begin{abstract}
Corruption in bank lending can seriously adversely affect credit allocation. Besides banking factors, national culture can also affect the corruption of bank officials. Prior studies have shown that collectivism increases bank corruption. This paper aims to assess the effects of cultural dimensions, besides collectivism, on the corruption of bank officials. Instead of using Hofstede's cultural data, this paper uses the data from the GLOBE project which is more recent and reports more cultural dimensions than Hofstede's. Using the data covering more than 3000 firms in 32 countries, this paper finds that humane orientation increases the corruption of bank officials. The effect of humane orientation on the corruption of bank officials is not only statistically significant but also economically relevant. The magnitude of its effect is relatively comparable to that of collectivism.
\end{abstract}

JEL Classification: G21, D73 Keywords: bank; corruption; culture; humane orientation

\section{Introduction}

Financial intermediaries including banks are expected to channel funds from lenders to deserving borrowers. Corruption in bank lending, however, may divert funds to undeserving borrowers. Beck et al. (2005) found that firms reporting being constrained by the corruption of bank officials tend to have lower growth rates. Beck et al. (2006) later studied the determinants of bank corruption to find that bank supervision affects the corruption of bank officials. More specifically, bank supervisory power increases the corruption but private monitoring of banks reduces it. The determinants of bank corruption have also been examined by a number of other researchers. Barth et al. (2009) found that bank competition and information sharing lower the corruption of bank officials. Dheera-aumpon (2015) found that the minority shareholder protection can also lower the corruption of bank officials.

Factors directly related to the banking sector, however, are not the only determinants of bank corruption. Zheng et al. (2013) and El Ghoul et al. (2016) both showed that cultural dimensions, especially collectivism, affect the corruption of bank officials. Particularly, collectivism increases the corruption of bank officials. It is important to note that both of them used cultural data from Hofstede (2001) which originally reports four cultural dimensions, including collectivism, masculinity, power distance and uncertainty avoidance.

Besides the Hofstede's, the GLOBE (Global Leadership and Organizational Behavior Effectiveness Research) project is an alternative source of cultural data. It reports nine cultural dimensions. Several of them are somewhat similar to those of Hofstede's while others are new and unique to the GLOBE project. New cultural dimensions include institutional 
collectivism, gender egalitarianism, performance orientation, and humane orientation. It is likely that those four new cultural dimensions also affect the corruption of bank officials.

This paper, therefore, aims to assess the effects of four cultural dimensions from the GLOBE project including institutional collectivism, gender egalitarianism, performance orientation, and humane orientation on the corruption of bank officials. It is important to note that the GLOBE project not only provides more cultural dimensions but also is more recent than Hofstede's. Namely, Hofstede conducted his survey between 1967 and 1973 while the GLOBE project conducted its survey during the 1990s. The time of the GLOBE project survey is much closer to that of the World Business Environment Survey (WBES) which reports data on the corruption of bank officials.

When a bank official decides whether to engage in corruption in the course of bank lending, he/she must compare the expected benefits with the costs of doing so. The expected costs of such corruption depend on the chance of being caught and reported as well as the level of punishment. Zheng et al. (2013) explained that collectivism increases the corruption of bank officials because it may decrease the likeliness that a fellow bank official reports on the corruption incident among his/her peers.

Institutional collectivism reflects the degree to which organizational and societal institutional practices encourage and reward collective distribution of resources and collective action. In a society with high institutional collectivism, group loyalty is encouraged even if the pursuit of individual goals in compromised. Seleim and Bontis (2009) found that high level of institutional collectivism is associated with low level of corruption. It is possible that bank officials in a society with high institutional collectivism are less likely to engage in corruption in the course of bank lending. In other words, institutional collectivism lowers the corruption level among bank officials. As a result, the following first hypothesis is proposed for our further study.

Hypothesis 1: A country's level of institutional collectivism is negatively related to the level of corruption among bank officials.

Gender egalitarianism reflects the degree to which a collective minimizes gender inequality. In a society with high gender egalitarianism, more women are in the position of authority. Recent studies including Charron and Bagenholm (2016), Fisar et al. (2016), Hao and Chang (2017) and Tuliao and Chen (2017) have found that more women are linked with less corruption. It is, therefore, likely that gender egalitarianism lowers the corruption of bank officials. Consequently, the following hypothesis is proposed.

Hypothesis 2: A country's level of gender egalitarianism is negatively related to the level of corruption among bank officials.

Performance orientation reflects the extent to which a community encourages and rewards innovation, high standards, excellence, and performance improvement. Seleim and Bontis (2009) found that high level of performance orientation is associated with low level of corruption. It is, therefore, likely that performance orientation lowers the corruption rate among bank officials. As a consequence, the following hypothesis is proposed.

Hypothesis 3: A country's level of performance orientation is negatively related to the level of corruption of bank officials.

Humane orientation reflects the degree to which an organization or society encourages and rewards individuals for being fair, altruistic, friendly, generous, caring, and kind to others. Seleim and Bontis (2009) found that high level of humane orientation is associated with high level of corruption. It is possible that fellow bank officials in a society with high level of humane orientation are less likely to report suspected corruption because they care about the well-being of their peers. It is, therefore, very likely that humane orientation raises the corruption among bank officials. Accordingly, the following hypothesis is proposed. 
Hypothesis 4: A country's level of humane orientation is positively related to the level of corruption of bank officials.

This paper uses the data covering more than 3000 firms in 32 countries for an ordered probit model. In agreement with Hypothesis 4, the results indicate that humane orientation increases the corruption of bank officials. The results, however, do not support other hypotheses. The effect of humane orientation on the corruption of bank officials is not only statistically significant but also economically significant. When humane orientation increases from the 25th percentile to the 75th percentile of the sample, the probability that an average firm will rate the corruption of bank officials as a major obstacle increases by 2.9 percentage points. Given that there is only $9 \%$ of firms rate the corruption of bank officials as a major obstacle, this 2.9-percentage point increase is relatively large. Also, this magnitude is quite large when compared to a 3.8-percentage point increase in the case of in-group collectivism. The results, therefore, suggest that a firm in a country with a high degree of humane orientation tends to face more corruption of bank officials. In other words, a firm in a society in which individuals are highly altruistic, friendly, caring, and kind to others tends to encounter more corruption of bank officials.

The remaining of the paper is organized as follows. Section 1 describes the data and the model. Section 2 presents the results and the last section concludes.

\section{Data and Model}

\subsection{Data and Variables}

In order to study the effect of humane orientation on bank corruption, this paper collects data in the same manner as Zheng et al. (2013) and El Ghoul et al. (2016). The sources of data and the descriptions of variables are as follows.

\subsubsection{Corruption of Bank Officials}

In this paper, corruption in bank lending is measured by firm responses to the relevant survey question from the World Business Environment Survey (WBES) conducted by the World Bank between late 1999 and early 2000. This survey includes both developed and developing countries, and covers firms of all sizes. The dependent variable, Bank Corruption, is constructed from the survey question asking the management of a firm to rate how problematic the corruption of bank officials is for the firm's operation and growth. The response takes a value of one if the answer is no obstacle, a value of two if it is minor obstacle, a value of three if it is moderate obstacle, and the value of four if it is major obstacle. It is important to note that the corruption of bank officials is different from the need for special connections with banks as shown by Dheera-aumpon $(2013,2016)$.

\subsubsection{Cultural Dimensions}

The GLOBE project cultural data are taken from House et al. (2004). Cultural dimensions from House et al. (2004) include (1) In-Group Collectivism, (2) Institutional Collectivism, (3) Assertiveness, (4) Gender Egalitarianism, (5) Power Distance, (6) Uncertainty Avoidance, (7) Future Orientation, (8) Performance Orientation, and (9) Humane Orientation. Five of them are to some extent similar to those of Hofstede (2001). Particularly, In-Group Collectivism, Assertiveness, Power Distance, Uncertainty Avoidance, and Future Orientation are somewhat close to Hofstede's Collectivism, Masculinity, Power 
Distance, Uncertainty Avoidance, and Long-Term Orientation, respectively. Therefore, Institutional Collectivism, Gender Egalitarianism, Performance Orientation, and Humane Orientation are quite new and unique. It is important to note that the GLOBE project reports two scores for each cultural dimension. Practices scores report what are practiced while values scores report what survey respondents feel should be. Given that bank corruption is more likely to be determined by how bank officials and their peers behave, the practices scores are rather appropriate and thus employed.

\subsubsection{Other Country-Level and Firm-Level Control Variables}

To control for bank supervision and bank competition, other country-level variables are introduced. Bank supervision variables are obtained from Barth et al. (2004) and include Supervisory Power and Private Monitoring. Supervisory Power measures the extent to which official bank supervisory authorities have the authority to take specific actions to prevent and correct problems. Private Monitoring measures private sector monitoring of banks. Both variables are the first principal components of pertinent dummy variables, with higher values indicating powerful bank supervision, and extensive private monitoring of banks, respectively. Bank Concentration which is taken from Beck et al. (2004) proxies for bank competition. It is the share of the assets held by the three largest banks in each country, averaged over 1995-1999.

To control for firm characteristics, firm-level variables are also introduced. Sales is the natural logarithm of firm sales. Government and Foreign dummy variables take a value of one if the government and foreign entities own any share of the firm, respectively, and zero otherwise. Manufacturing and Services dummy variables take a value of one if the firm is in the manufacturing sector and the service sector, respectively, and zero otherwise. Export dummy variable takes a value of one if the firm exports, and zero otherwise. The Number of Competitors represents the number of competitors the firm encounters in its main market.

To check the robustness of the results, several additional country-level control variables will be introduced later on. Growth is the growth rate of GDP obtained from the World Development Indicators (WDI), averaged over 1995-1999. Inflation used as a proxy for monetary instability is the log difference of consumer price index taken from the International Financial Statistics (IFS), averaged over 1995-1999. Private Credit obtained from Beck et al. (2004) is the share of claims by financial institutions on the private sector in GDP and is used as a measure of financial development. Anti-Director taken from Djankov et al. (2008) is an index measuring the protection of minority shareholders against expropriation by management. Rule of Law obtained from Kaufmann et al. (2010) is an index measuring the extent to which agents have confidence in and abide by the rules of society. Financing Constraint taken from the WBES is a firm's response to the question how problematic the external financing is for the firm's operation and growth. General Corruption obtained from the WBES is a firm's response to the question how problematic the general corruption is for the firm's operation and growth.

The combined data include 3029 firms covering 32 countries including Argentina, Bolivia, Brazil, Canada, Chile, Egypt, El Salvador, France, Germany, Guatemala, Hungary, India, Indonesia, Italy, Malaysia, Mexico, Nigeria, Philippines, Poland, Portugal, Russia, Singapore, Slovenia, South Africa, Spain, Sweden, Thailand, Turkey, United Kingdom, United States, Venezuela, and Zambia. Table 1 reports summary statistics including the mean, standard deviation, minimum, maximum and number of observations of each variable. In Appendix A, Table Al lists all variables with their descriptions and sources. 
Table 1. Summary statistics

\begin{tabular}{lccccc}
\hline Variable & Mean & $\begin{array}{c}\text { Standard } \\
\text { deviation }\end{array}$ & Minimum & Maximum & $\begin{array}{c}\text { Number of } \\
\text { observations }\end{array}$ \\
\hline Bank Corruption & 1.620 & 0.978 & 1 & 4 & 3029 \\
\hline Institutional Collectivism & 4.173 & 0.364 & 3.63 & 5.26 & 32 \\
\hline Gender Egalitarianism & 3.405 & 0.336 & 2.88 & 4.07 & 32 \\
\hline Performance Orientation & 3.983 & 0.342 & 3.41 & 4.81 & 32 \\
\hline Humane Orientation & 4.036 & 0.476 & 3.29 & 5.12 & 32 \\
\hline In-Group Collectivism & 5.267 & 0.614 & 3.46 & 6.14 & 32 \\
\hline Assertiveness & 4.103 & 0.336 & 3.41 & 4.715 & 32 \\
\hline Power Distance & 5.230 & 0.311 & 4.46 & 5.68 & 32 \\
\hline Uncertainty Avoidance & 4.054 & 0.573 & 3.09 & 5.36 & 32 \\
\hline Future Orientation & 3.780 & 0.437 & 3.06 & 4.88 & 32 \\
\hline Supervisory Power & -0.125 & 1.143 & -3.048 & 1.138 & 32 \\
\hline Private Monitoring & 0.313 & 0.720 & -1.255 & 1.458 & 32 \\
\hline Bank Concentration & 57.270 & 18.769 & 21.838 & 94.684 & 32 \\
\hline Sales & 11.666 & 7.686 & -2.120 & 25.328 & 3029 \\
\hline Government & 0.103 & 0.304 & 0 & 1 & 3029 \\
\hline Foreign & 0.203 & 0.403 & 0 & 1 & 3029 \\
\hline Export & 0.385 & 0.487 & 0 & 1 & 3029 \\
\hline Manufacturing & 0.369 & 0.483 & 0 & 1 & 3029 \\
\hline Services & 0.470 & 0.499 & 0 & 1 & 3029 \\
\hline Number of Competitors & 2.255 & 0.707 & 0 & 4 & 3029 \\
\hline Growth & 3.452 & 1.888 & -1.049 & 9.137 & 32 \\
\hline Inflation & 13.473 & 19.327 & 0.767 & 80.739 & 30 \\
\hline Private Credit & 51.906 & 38.720 & 4.232 & 145.292 & 31 \\
\hline Anti-Director & 3.379 & 1.265 & 1 & 5 & 29 \\
\hline Rule of Law & 0.329 & 0.944 & -1.272 & 1.771 & 32 \\
\hline Financing Obstacle & 2.628 & 1.141 & 1 & 4 & 2937 \\
\hline General Corruption & 2.319 & 1.173 & 1 & 4 & \\
\hline Note: This table reports the summary statistics for all variables & in the regressions. Description and sources of all \\
variables are presented in Table Al in Appendix & A. & & & & \\
\hline
\end{tabular}

\subsection{Model and Method}

A firm's underlying response to the pertinent survey question is assumed to be described by the following equation:

Bank Corruption $_{i, j}=\alpha+\beta_{1}$ Institutional Collectivism $_{j}+\beta_{2}$ Gender Egalitarianism $_{j}$

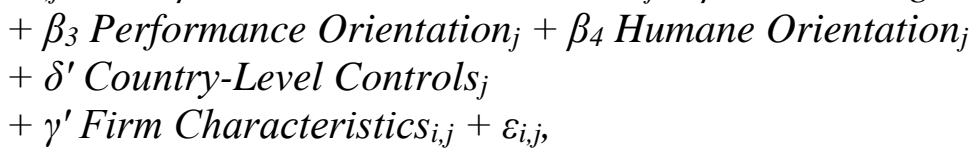

where the $i$ and $j$ subscripts indicate firm and country, respectively. Country-Level Controls is a vector of other country-level control variables. Specifically, Country-Level Controls $=($ InGroup Collectivism, Assertiveness, Power Distance, Uncertainty Avoidance, Future Orientation, Supervisory Power, Private Monitoring, Bank Concentration)'. $\delta$ is accordingly a vector of coefficients of other country-level controls. Firm Characteristics is a vectors of firmlevel control variables. Specifically, Firm Characteristics $=$ (Sales, Government, Foreign, Manufacturing, Services, Export, Number of Competitors)'. $\gamma$ is accordingly a vector of coefficients of firm characteristics.

Unlike the underlying response, the observed response is an ordered categorical variable with four categories. The ordered probit model is, therefore, employed. The details of 
ordered probit is explained in Appendix B. The standard maximum likelihood estimation with heteroscedasticity robust standard errors is used. Following Beck et al. (2006), standard errors are clustered at the country level. Specifically, error terms are allowed to be correlated across firms within the same country but are required to be independent across countries. The pseudo $\mathrm{R}$-squared which is a measure of goodness of fit of the model is also reported.

\section{Results}

\subsection{Effects of Culture on Bank Corruption}

The results from ordered probit regressions of Bank Corruption on various cultural dimensions are reported in Table 2. Besides four cultural dimensions including Institutional Collectivism, Gender Egalitarianism, Performance Orientation, and Humane Orientation, other cultural dimensions, other country-level controls and firm-level controls are introduced into the regressions.

Table 2. Cultural dimensions and Bank Corruption

\begin{tabular}{|c|c|c|c|c|c|c|}
\hline & \multicolumn{2}{|c|}{ (1) } & \multicolumn{2}{|c|}{ (2) } & \multicolumn{2}{|c|}{ (3) } \\
\hline Institutional Collectivism & -0.0698 & $(0.351)$ & & & & \\
\hline Gender Egalitarianism & -0.444 & $(0.283)$ & & & & \\
\hline Performance Orientation & -0.100 & $(0.310)$ & & & & \\
\hline Humane Orientation & $0.565^{*}$ & $(0.282)$ & $0.408^{*}$ & $(0.188)$ & $0.540^{* *}$ & $(0.212)$ \\
\hline In-Group Collectivism & $0.544^{* * * *}$ & $(0.148)$ & $0.559^{* * *}$ & $(0.170)$ & & \\
\hline Assertiveness & 0.547 & $(0.397)$ & & & & \\
\hline Power Distance & -0.0806 & $(0.250)$ & & & & \\
\hline Uncertainty Avoidance & 0.389 & $(0.231)$ & & & & \\
\hline Future Orientation & -0.441 & $(0.243)$ & & & & \\
\hline Supervisory Power & 0.0739 & $(0.0626)$ & 0.0847 & $(0.0656)$ & 0.136 & $(0.0803)$ \\
\hline Private Monitoring & -0.177 & $(0.128)$ & -0.00255 & $(0.137)$ & -0.133 & $(0.162)$ \\
\hline Bank Concentration & 0.000749 & $(0.00408)$ & -0.000769 & $(0.00351)$ & 0.000960 & $(0.00393)$ \\
\hline Sales & -0.00186 & $(0.0114)$ & 0.00378 & $(0.0140)$ & -0.00330 & $(0.0186)$ \\
\hline Government & $-0.303^{* *}$ & $(0.128)$ & $-0.296^{*}$ & $(0.133)$ & $-0.276^{*}$ & $(0.138)$ \\
\hline Foreign & $-0.151^{* *}$ & $(0.0643)$ & $-0.135^{*}$ & $(0.0690)$ & -0.0831 & $(0.0636)$ \\
\hline Manufacturing & $-0.213^{*}$ & $(0.0986)$ & $-0.231^{* *}$ & $(0.0885)$ & -0.160 & $(0.0947)$ \\
\hline Services & -0.0371 & $(0.133)$ & -0.0834 & $(0.117)$ & -0.0764 & $(0.120)$ \\
\hline Export & -0.113 & $(0.0636)$ & -0.0754 & $(0.0700)$ & -0.117 & $(0.0690)$ \\
\hline Number of Competitors & 0.0236 & $(0.0684)$ & 0.0477 & $(0.0780)$ & 0.0752 & $(0.0783)$ \\
\hline Countries & & 2 & & & & 2 \\
\hline Observations & & 29 & & & & 29 \\
\hline Pseudo $\mathrm{R}^{2}$ & & 75 & & & & 44 \\
\hline
\end{tabular}

In the first specification, all cultural dimension and controls are included. The coefficient of Humane Orientation is positive and statistically significant at 10 percent level. This indicates that firms in a country with a high degree of humane orientation face more corruption of bank officials. In-Group Collectivism also enters positively and significantly at 1 percent level. Consistent with Zheng et al. (2013), this confirms that firms in a country with 
a high degree of collectivism encounter more corruption of bank officials. Other cultural dimensions, however, do not enter significantly.

From the second specification onward, cultural dimensions except Humane Orientation and In-Group Collectivism are dropped. Humane Orientation still enters positively and significantly at 10 percent level. In the third specification, In-Group Collectivism is dropped. Humane Orientation then enters positively and significantly at 5 percent level instead. It is possibly because Humane Orientation and In-Group Collectivism are quite positively correlated.

Among other control variables, only Government always enters negatively and significantly. This indicates that firms with government ownership tend to face less corruption of bank officials. Other controls including Supervisory Power, Private Monitoring, Bank Concentration, Sales, Foreign, Manufacturing, Services, Export, and Number of Competitors do not always enter significantly.

In sum, the coefficient of Humane Orientation is always positive and statistically significant at 10 percent level. In accordance with Hypothesis 4, the results indicate that firms in a country with a high degree of humane orientation tend to face more corruption of bank officials. The results, however, do not support other hypotheses.

\subsection{Economic Significance}

Besides being statistically significant, the effect of humane orientation on bank corruption is also economically relevant. To assess the magnitude of the effect, the estimated probabilities that an average firm will rate the corruption of bank officials as no obstacle, a minor obstacle, a moderate obstacle, and a major obstacle at different levels of Humane Orientation are computed. Humane Orientation is set at either the $25^{\text {th }}, 50^{\text {th }}$ or $75^{\text {th }}$ percentile of the sample while holding other variables constant at their sample means. Changes in the estimated probabilities when Humane Orientation is changed are also calculated. In order to compare the magnitude of the effect of Humane Orientation to that of In-Group Collectivism, the estimated probabilities and their changes at different levels of In-Group Collectivism are also computed.

Table 3 presents the estimated probabilities and their changes based on the second specification in Table 2. The second specification is conservatively chosen because it had the smallest coefficient of Humane Orientation. The estimates indicate that if Humane Orientation changes from the $25^{\text {th }}$ percentile (3.728) to the $75^{\text {th }}$ percentile $(4.330)$, the probability that an average firm would rate the corruption of bank officials as a major obstacle increases from $4.6 \%$ to $7.4 \%$. This 2.9 -percentage-point increase is relatively large as only $9 \%$ of firms in the sample rated the corruption of bank officials as a major obstacle. This 2.9percentage-point increase is also quite large when compared to a 3.8-percentage-point increases resulting from a change in In-Group Collectivism. This confirms that the effect of humane orientation on bank corruption is economically significant. In sum, the results confirm that there is a significant and positive association between a country's level of humane orientation and the level of corruption of bank officials. 
Table 3. Cultural dimensions and Bank Corruption - magnitude of the effect

\begin{tabular}{|c|c|c|c|c|c|c|}
\hline $\begin{array}{l}\text { Humane } \\
\text { Orientation } \\
\text { at }\end{array}$ & $\begin{array}{c}25^{\text {th }} \\
\text { percentile } \\
(3.728)\end{array}$ & $\begin{array}{c}50^{\text {th }} \\
\text { percentile } \\
(3.958) \\
\end{array}$ & $\begin{array}{c}75^{\text {th }} \\
\text { percentile } \\
(4.330) \\
\end{array}$ & $\begin{array}{l}\text { Change btw } \\
25^{\text {th }} \text { and } 50^{\text {th }} \\
\% \text { tiles }\end{array}$ & $\begin{array}{c}\text { Change btw } \\
50^{\text {th }} \text { and } 75^{\text {th }} \\
\% \text { tiles }\end{array}$ & $\begin{array}{c}\text { Change btw } \\
25^{\text {th }} \text { and } 75^{\text {th }} \\
\% \text { tiles }\end{array}$ \\
\hline \multicolumn{7}{|c|}{ Estimated probability that an average firm will rate the corruption of bank officials as: } \\
\hline No obstacle & 0.742 & 0.711 & 0.657 & -0.031 & -0.054 & -0.085 \\
\hline Minor obst. & 0.150 & 0.163 & 0.182 & & & \\
\hline Mod. obst. & 0.062 & 0.071 & 0.086 & & & \\
\hline Major obst. & 0.046 & 0.055 & 0.074 & 0.010 & 0.019 & 029 \\
\hline $\begin{array}{l}\text { In-Group } \\
\text { Collectivism } \\
\text { at }\end{array}$ & $\begin{array}{c}25^{\text {th }} \\
\text { percentile } \\
(5.118)\end{array}$ & $\begin{array}{c}50^{\text {th }} \\
\text { percentile } \\
(5.490) \\
\end{array}$ & $\begin{array}{c}75^{\text {th }} \\
\text { percentile } \\
(5.645) \\
\end{array}$ & $\begin{array}{c}\text { Change btw } \\
10^{\text {th }} \text { and } 25^{\text {th }} \\
\% \text { tiles }\end{array}$ & $\begin{array}{c}\text { Change btw } \\
25^{\text {th }} \text { and } 50^{\text {th }} \\
\% \text { tiles }\end{array}$ & $\begin{array}{c}\text { Change btw } \\
50^{\text {th }} \text { and } 75^{\text {th }} \\
\% \text { tiles }\end{array}$ \\
\hline \multicolumn{7}{|c|}{ Estimated probability that an average firm will rate the corruption of bank officials as: } \\
\hline No obstacle & 0.729 & 0.656 & 0.623 & -0.073 & -0.032 & -0.105 \\
\hline Minor obst. & 0.156 & 0.183 & 0.193 & & 0.010 & 38 \\
\hline Mod. obst. & 0.066 & 0.087 & 0.096 & 0.0 & 0.009 & 0.030 \\
\hline Major obst. & 0.050 & 0.075 & 0.088 & 0.025 & 0.013 & 0.038 \\
\hline \multicolumn{7}{|c|}{$\begin{array}{l}\text { Note: This table presents the magnitude of the effects of Humane Orientation and In-Group Collectivism on } \\
\text { estimated probabilities which an average firm will rate the corruption of bank officials as no obstacles, a minor } \\
\text { obstacle, a moderate obstacle, and a major obstacle. Based on Specification } 2 \text { in Table } 2 \text {, estimated probabilities } \\
\text { are presented for the } 25^{\text {th }}, 50^{\text {th }} \text { and } 75^{\text {th }} \text { percentiles of Humane Orientation or In-Group Collectivism. Estimated } \\
\text { probabilities are calculated setting all variables at their actual average values, except Humane Orientation or In- } \\
\text { Group Collectivism, which is set at either the } 25^{\text {th }}, 50^{\text {th }} \text { or } 75^{\text {th }} \text { percentile of the sample. }\end{array}$} \\
\hline
\end{tabular}

\subsection{Robustness Checks}

To checks the robustness of the results, several additional country-level variables will be introduced into the regressions as additional controls. Table 4 presents the results from these regressions. In the first column, Growth which is the growth rate of GDP is introduced. Growth enters negatively but not significantly. Humane Orientation still enters positively and significantly at 5 percent level. In the second column, Inflation which is the rate of inflation is introduced. While Inflation enters positively and significantly, Humane Orientation still enters positively and significantly at 5 percent level. In the third column, Private Credit which is a measure of financial development is introduced. In the forth specification, Anti-Director which is an index of minority shareholder protection is introduced. Private Credit and AntiDirector enter negatively and positively but both not significantly. Humane Orientation still enters positively and significantly. In the fifth specification, Rule of Law which is a measure of institutional development is introduced. While Rule of Law enters negatively and significantly, Humane Orientation still enters positively and significantly at 5 percent level.

Because Bank Corruption is a firm's response to a survey question, it may suffer from a perception bias. The regressions may also suffer from an omitted-variable bias. In the sixth and the seventh columns, Financing Constraint and General Corruption which are firm's responses to different but related survey questions are introduced. They are chosen because if there is a perception bias they are probably biased in the same way as Bank Corruption. Also, they are likely to be determined by a comparable set of explanatory variables. By including these variables, any perception bias and any omitted-variable bias should be reduced. While Financing Constraint and General Corruption enter positively and significantly, Humane Orientation still enters positively and significantly. 
Table 4. Humane Orientation and Bank Corruption - controlling for other factors

\begin{tabular}{|c|c|c|c|c|c|c|c|}
\hline & (1) & (2) & (3) & (4) & (5) & (6) & $(7)$ \\
\hline Humane & $0.546^{* *}$ & $0.522^{* *}$ & $0.497^{*}$ & $0.612^{* *}$ & $0.520^{* *}$ & $0.523^{* *}$ & $0.438^{*}$ \\
\hline Orientation & $(0.227)$ & $(0.214)$ & $(0.227)$ & $(0.240)$ & $(0.213)$ & $(0.194)$ & $(0.197)$ \\
\hline Growth & $\begin{array}{l}-0.00353 \\
(0.0322)\end{array}$ & & & & & & \\
\hline Inflation & & $\begin{array}{c}0.0107^{* *} \\
(0.00412)\end{array}$ & & & & & \\
\hline Private Credit & & & $\begin{array}{c}0.00183 \\
(0.00286) \\
\end{array}$ & & & & \\
\hline Anti-Director & & & & $\begin{array}{l}-0.0692 \\
(0.0564)\end{array}$ & & & \\
\hline Rule of Law & & & & & $\begin{array}{l}-0.276^{* * *} \\
(0.110)\end{array}$ & & \\
\hline Financing & & & & & & $0.290^{* * *}$ & \\
\hline Constraint & & & & & & $(0.0282)$ & \\
\hline General & & & & & & & $0.432^{* * *}$ \\
\hline Corruption & & & & & & & $(0.0318)$ \\
\hline $\begin{array}{l}\text { Other Control } \\
\text { Variables }\end{array}$ & Supervis & $\begin{array}{r}\text { Power, Pri } \\
\text { Manuf }\end{array}$ & $\begin{array}{l}\text { Monitoring } \\
\text { ring, Servic }\end{array}$ & $\begin{array}{l}\text { ank Conce } \\
\text { Export, } \mathrm{Nu}\end{array}$ & $\begin{array}{l}\text { tion, Sal } \\
\text { er of Con }\end{array}$ & $\begin{array}{l}\text { Governme } \\
\text { itors }\end{array}$ & Foreign, \\
\hline Countries & 32 & 30 & 31 & 29 & 32 & 32 & 32 \\
\hline Observations & 3029 & 2885 & 2964 & 2814 & 3029 & 2909 & 2837 \\
\hline Pseudo $\mathrm{R}^{2}$ & 0.044 & 0.060 & 0.046 & 0.053 & 0.056 & 0.069 & 0.11 \\
\hline
\end{tabular}

Note: This table presents the results from ordered probit regressions of Bank Corruption on various country-level and firm-level control variables. Description and sources of all variables are presented in Table Al in Appendix A. The errors are clustered at the country level. Robust clustered standard errors are reported in parentheses. $* * * * * * *$ indicate significance at the 1,5 , and 10 percent level, respectively.

Table 5. Humane Orientation and Bank Corruption - robustness checks

\begin{tabular}{|c|c|c|c|c|c|c|c|c|}
\hline \multirow[b]{2}{*}{ Humane Orientation } & \multicolumn{2}{|c|}{$\begin{array}{c}\text { (1) } \\
\text { Order probit } \\
3 \text { categories }\end{array}$} & \multicolumn{2}{|c|}{$\begin{array}{c}(2) \\
\text { Probit } \\
2 \text { categories }\end{array}$} & \multicolumn{2}{|c|}{$\begin{array}{c}\text { (3) } \\
\text { Only firms with } \\
\text { bank finance }\end{array}$} & \multicolumn{2}{|c|}{$\begin{array}{c}\text { (4) } \\
\text { Only firms without } \\
\text { bank finance }\end{array}$} \\
\hline & $0.55^{* *}$ & $(0.22)$ & $0.53^{*}$ & $(0.24)$ & $0.61^{\text {** }}$ & $(0.26)$ & $0.58^{* *}$ & $(0.25)$ \\
\hline Supervisory Power & 0.15 & $(0.081)$ & 0.16 & $(0.084)$ & 0.11 & $(0.10)$ & 0.10 & $(0.097)$ \\
\hline Private Monitoring & -0.12 & $(0.16)$ & -0.12 & $(0.16)$ & -0.080 & $(0.15)$ & -0.11 & $(0.19)$ \\
\hline Bank Concentration & 0.0010 & $(0.0040)$ & -0.00043 & $(0.0040)$ & 0.0025 & $(0.0043)$ & 0.0028 & $(0.0051)$ \\
\hline Sales & -0.0028 & $(0.019)$ & 0.0014 & $(0.019)$ & 0.0039 & $(0.018)$ & -0.0058 & $(0.020)$ \\
\hline Government & $-0.31^{*}$ & $(0.14)$ & $-0.32^{* *}$ & $(0.14)$ & -0.23 & $(0.15)$ & -0.27 & $(0.16)$ \\
\hline Foreign & -0.089 & $(0.062)$ & -0.097 & $(0.069)$ & -0.10 & $(0.091)$ & -0.072 & $(0.087)$ \\
\hline Manufacturing & -0.18 & $(0.090)$ & -0.17 & $(0.089)$ & -0.15 & $(0.11)$ & -0.17 & $(0.12)$ \\
\hline Services & -0.090 & $(0.11)$ & -0.092 & $(0.11)$ & -0.079 & $(0.12)$ & -0.11 & $(0.13)$ \\
\hline Export & -0.10 & $(0.074)$ & -0.12 & $(0.071)$ & -0.12 & $(0.078)$ & -0.19 & $(0.10)$ \\
\hline $\begin{array}{l}\text { Number of } \\
\text { Competitors }\end{array}$ & 0.093 & $(0.081)$ & 0.11 & $(0.079)$ & 0.16 & $(0.088)$ & 0.041 & $(0.087)$ \\
\hline Countries & & & & & & & & \\
\hline Observations & & & & & & & & \\
\hline Pseudo $\mathrm{R}^{2}$ & & & & & & & & \\
\hline \multicolumn{9}{|c|}{$\begin{array}{l}\text { Note: This table presents the results from ordered probit regressions of Bank Corruption on various country-level } \\
\text { and firm-level control variables. Description and sources of all variables are presented in Table Al in } \\
\text { Appendix A. In the first column, the last two categories of Bank Corruption are grouped so that there are three } \\
\text { categories. In the second column, he last three categories of Bank Corruption are grouped so that there are only } \\
\text { two categories and the probit model is employed instead. In the third column, only firms receiving bank } \\
\text { financing are included. In the forth column, only firms receiving no bank financing are included. The errors are } \\
\text { clustered at the country level. Robust clustered standard errors are reported in parentheses. ***,*** indicate } \\
\text { significance at the } 1,5 \text {, and } 10 \text { percent level, respectively. }\end{array}$} \\
\hline
\end{tabular}


Because the responses to the survey question are not quite evenly distributed across four categories and there are relatively small numbers of firms in some categories, there may be a concern regarding the reliability of the results. In particular, $65 \%, 17 \%, 9 \%$, and $9 \%$ of firms responded that the corruption of bank officials is no obstacle, a minor obstacle, a moderate obstacle and a major obstacle, respectively. In the first and the second columns of Table 5, the last two categories are grouped and the last three categories are grouped to make the distribution more even. There may be a concern that the results are driven by disgruntled borrowers who cannot get bank financing. In the third and forth columns of Table 5, the sample is split into two subsamples - one with only firms that receive bank financing and one with only firms that do not receive bank financing. The results in Table 5 show that Humane Orientation still enters positively and significantly.

In sum, the results so far are robust and indicate in accordance with Hypothesis 4 that an average firm in a country with a high degree of humane orientation tends to come across more corruption of bank officials.

\section{Conclusion}

This paper aims to evaluate the effects of cultural dimensions beside of collectivism on the corruption of bank officials. Different from prior studies that use Hofstede's cultural data, this paper uses cultural data from the GLOBE project. Hofstede originally reports four cultural dimensions while the GLOBE project reports nine dimensions. Some of them are similar whereas others are new and unique to the GLOBE project. New cultural dimensions include institutional collectivism, gender egalitarianism, performance orientation and humane orientation. It is likely that those four new cultural dimensions also affect the corruption of bank officials.

The results indicate that humane orientation increases the corruption of bank officials. The effect of humane orientation on the corruption of bank officials is not only statistically significant but also economically relevant. The magnitude of the effect is quite comparable to that of collectivism. The results are robust to controlling for other factors and are not driven by a perception bias, by the distribution of the survey responses or by disgruntled borrowers. The results, therefore, confirm that a firm in a country with a high level of humane orientation tends to face more corruption of bank officials. In other words, a firm in a society in which individuals are highly altruistic, friendly, caring, and kind to others tends to encounter more corruption of bank officials. To curb the corruption of bank officials, policymakers thus should pay special attention to countries with a high level of humane orientation as they tend to have more corruption in bank lending.

\section{Acknowledgement}

The author would like to thank Manachaya Uruyos, Woradee Jongadsayakul, Thanarak Laosuthi, and anonymous reviewers for their helpful comments and suggestions. The author is also grateful for the research grant from the Department of Economics at Kasetsart University.

\section{References}

Barth, J. R., Caprio, G. Jr., \& Levine, R. (2004). Bank regulation and supervision: what works best? Journal of Financial Intermediation, 13, 205-248. 
Barth, J. R., Lin, C., Lin, P., \& Song, F. M. (2009). Corruption in bank lending to firms: Cross-country micro evidence on the beneficial role of competition and information sharing. Journal of Financial Economics, 91, 361-388.

Beck, T., Demirguc-Kunt, A., \& Levine, R. (2006). Bank supervision and corruption in lending. Journal of Monetary Economics, 53, 2131-2163.

Beck, T., Demirguc-Kunt, A., \& Maksimovic, V. (2004). Bank Competition and Access to Finance: international evidence. Journal of Money, Credit and Banking, 36, 627-648.

Beck, T., Demirguc-Kunt, A., \& Maksimovic, V. (2005). Financial and legal constraints to growth: does firm size matter? Journal of Finance, 60, 137-177.

Charron, N., \& Bagenholm, A. (2016). Ideology, party systems and corruption voting in european democracies. Electoral Studies, 41, 36-49.

Dheera-aumpon, S. (2013). Connected lending and concentrated control. Journal of Financial Stability, 9, 475-486.

Dheera-aumpon, S. (2015). Can shareholder rights protection reduce corruption in lending? International Journal of Monetary Economics and Finance, 8, 178-190.

Dheera-aumpon, S. (2016). Bank ownership and connected lending. International Review of Economics and Finance, 41, 274-286.

Djankov, S., La Porta, R., Lopez-de-Silanes, F., \& Shleifer, A. (2008). The law and economics of self-dealing. Journal of Financial Economics, 88, 430-465.

El Ghoul, S., Guedhami, O., Kwok, C. C. Y., \& Zheng, X. (2016). Collectivism and corruption in commercial loan production: How to break the curse? Journal of Business Ethics, 139, 225-250.

Fisar, M., Kubak, M., Spalek, J., \& Tremewan, J. (2016). Gender differences in beliefs and actions in a framed corruption experiment. Journal of Behavioral and Experimental Economics, 63, 69-82.

Hao, Y., \& Chang, C.-P. (2017). Women and corruption: evidence from multinational panel data. Quality \& Quantity, Advance online publication.

Hofstede, G. H. (2001). Culture's consequences: International Differences in Work-Related Values (2nd ed.). Thousand Oaks, CA: Sage.

House, R. J., Hanges, P. J., Javidan, M., Dorfman, P. W., \& Gupta, V. (2004). Culture, Leadership, and Organizations: The GLOBE Study of 62 Societies. Thousand Oaks, CA: Sage.

Kaufmann, D., Kraay, A., \& Mastruzzi, M. (2010). The worldwide governance indicators: methodology and analytical issues. World Bank Policy Research Working Paper, 5430.

Seleim, A., \& Bontis, N. (2009). The relationship between culture and corruption: a crossnational study. Journal of Intellectual Capital, 10, 165-184.

Tuliao, K. V., \& Chen, C. (2017). CEO duality and bribery: the roles of gender and national culture. Management Decision, 55, 218-231.

Zheng, X., El Ghoul, S., Guedhami, O., \& Kwok, C. C. Y. (2013). Collectivism and corruption in bank lending. Journal of International Business Studies, 44, 363-390. 


\section{Appendix A}

\section{Table A1. Variable descriptions and sources}

\begin{tabular}{|c|c|c|}
\hline Variable & Description & Source \\
\hline $\begin{array}{l}\text { Bank } \\
\text { Corruption }\end{array}$ & $\begin{array}{l}\text { How problematic is the corruption of bank officials for the operation and growth of } \\
\text { your business? } 1 \text { is no obstacle, } 2 \text { is minor obstacle, } 3 \text { is moderate obstacle, and } 4 \text { is } \\
\text { major obstacle. }\end{array}$ & $\begin{array}{l}\text { World Business } \\
\text { Environment } \\
\text { Survey (WBES) }\end{array}$ \\
\hline $\begin{array}{l}\text { Institutional } \\
\text { Collectivism }\end{array}$ & $\begin{array}{l}\text { National culture index measuring the degree to which organizational and societal } \\
\text { institutional practices encourage and reward collective distribution of resources and } \\
\text { collective action. (practices score) }\end{array}$ & $\begin{array}{l}\text { House et al. } \\
\text { (2004) }\end{array}$ \\
\hline $\begin{array}{l}\text { Gender } \\
\text { Egalitarianism }\end{array}$ & $\begin{array}{l}\text { National culture index measuring the degree to which a collective minimizes gender } \\
\text { inequality. (practices score) }\end{array}$ & $\begin{array}{l}\text { House et al. } \\
(2004)\end{array}$ \\
\hline $\begin{array}{l}\text { Performance } \\
\text { Orientation }\end{array}$ & $\begin{array}{l}\text { National culture index measuring the extent to which a community encourages and } \\
\text { rewards innovation, high standards, excellence, and performance improvement. } \\
\text { (practices score) }\end{array}$ & $\begin{array}{l}\text { House et al. } \\
(2004)\end{array}$ \\
\hline $\begin{array}{l}\text { Humane } \\
\text { Orientation }\end{array}$ & $\begin{array}{l}\text { National culture index measuring the degree to which an organization or society } \\
\text { encourages and rewards individuals for being fair, altruistic, friendly, generous, caring, } \\
\text { and kind to others. (practices score) }\end{array}$ & $\begin{array}{l}\text { House et al. } \\
(2004)\end{array}$ \\
\hline $\begin{array}{l}\text { In-Group } \\
\text { Collectivism }\end{array}$ & $\begin{array}{l}\text { National culture index measuring the degree to which individuals express pride, } \\
\text { loyalty, and cohesiveness in their organizations or families. (practices score) }\end{array}$ & $\begin{array}{l}\text { House et al. } \\
(2004)\end{array}$ \\
\hline Assertiveness & $\begin{array}{l}\text { National culture index measuring the degree to which individuals are assertive, } \\
\text { confrontational, and aggressive in their relationships with others. (practices score) }\end{array}$ & $\begin{array}{l}\text { House et al. } \\
(2004)\end{array}$ \\
\hline Power Distance & $\begin{array}{l}\text { National culture index measuring the degree to which members of an organization or } \\
\text { society expect and agree that power should be unequally shared. (practices score) }\end{array}$ & $\begin{array}{l}\text { House et al. } \\
(2004)\end{array}$ \\
\hline $\begin{array}{l}\text { Uncertainty } \\
\text { Avoidance }\end{array}$ & $\begin{array}{l}\text { National culture index measuring the extent to which a society, organization, or group } \\
\text { relies on social norms, rules, and procedures to alleviate the unpredictability of future } \\
\text { events. (practices score) }\end{array}$ & $\begin{array}{l}\text { House et al. } \\
(2004)\end{array}$ \\
\hline $\begin{array}{l}\text { Future } \\
\text { Orientation }\end{array}$ & $\begin{array}{l}\text { National culture index measuring the degree to which a collectivity encourages and } \\
\text { rewards future-oriented behaviors such as planning and delaying gratification. } \\
\text { (practices score) }\end{array}$ & $\begin{array}{l}\text { House et al. } \\
(2004)\end{array}$ \\
\hline $\begin{array}{l}\text { Supervisory } \\
\text { Power }\end{array}$ & $\begin{array}{l}\text { First principal component of } 14 \text { dummy variables: (1) Does the supervisory agency } \\
\text { have the right to meet with external auditors to discuss their report without the } \\
\text { approval of the bank? (2) Are auditors required by law to communicate directly to the } \\
\text { supervisory agency any presumed involvement of bank directors or senior managers in } \\
\text { illicit activities, fraud, or insider abuse? (3) Can supervisors take legal action against } \\
\text { external auditors for negligence? (4) Can the supervisory authority force a bank to } \\
\text { change its internal organizational structure? (5) Are off-balance sheet items disclosed } \\
\text { to supervisors? (6) Can the supervisory agency order the bank's directors or } \\
\text { management to constitute provisions to cover actual or potential losses? (7) Can the } \\
\text { supervisory agency suspend the directors' decision to distribute: (a) Dividends? (b) } \\
\text { Bonuses? (c) Management fees? (8) Can the supervisory agency legally declare- } \\
\text { such that this declaration supersedes the rights of bank shareholders-that a bank is } \\
\text { insolvent? (9) Does the Banking Law give authority to the supervisory agency to } \\
\text { intervene-that is, suspend some or all ownership rights-a problem bank? (10) } \\
\text { Regarding bank restructuring and reorganization, can the supervisory agency or any } \\
\text { other government agency do the following: (a) Supersede shareholder rights? (b) } \\
\text { Remove and replace management? (c) Remove and replace directors? }\end{array}$ & $\begin{array}{l}\text { Barth et al. } \\
\text { (2004) }\end{array}$ \\
\hline $\begin{array}{l}\text { Private } \\
\text { Monitoring }\end{array}$ & $\begin{array}{l}\text { First principal component of } 9 \text { dummy variables: (1) Are bank directors legally liable } \\
\text { if information disclosed is erroneous or misleading? (2) Are financial institutions } \\
\text { required to produce consolidated accounts covering all bank and any non-bank } \\
\text { financial subsidiaries? (3) Is an external audit a compulsory obligation for banks? (4) } \\
\text { Are the top ten banks rated by international credit rating agencies? (5) Are off-balance } \\
\text { sheet items disclosed to the public? (6) Must banks disclose their risk management } \\
\text { procedures to the public? (7) Does accrued, though unpaid, interest/principal enter the } \\
\text { income statement while the loan is still non-performing? (8) Is subordinated debt } \\
\text { allowable as part of capital? (9) Is there no explicit deposit insurance protection } \\
\text { system or compensation paid the last time a bank failed? }\end{array}$ & $\begin{array}{l}\text { Barth et al. } \\
(2004)\end{array}$ \\
\hline $\begin{array}{l}\text { Bank } \\
\text { Concentration }\end{array}$ & $\begin{array}{l}\text { Share of the assets held by the largest three banks in each country, averaged over } \\
1995-1999 .\end{array}$ & $\begin{array}{l}\text { Beck et al. } \\
(2004)\end{array}$ \\
\hline Sales & Natural logarithm of firm sales. & WBES \\
\hline Government & $\begin{array}{l}\text { Dummy variable equals } 1 \text { if the government owns any share of the firm, and } 0 \\
\text { otherwise. }\end{array}$ & WBES \\
\hline Foreign & $\begin{array}{l}\text { Dummy variable equals } 1 \text { if foreign entities own any share of the firm, and } 0 \\
\text { otherwise. }\end{array}$ & WBES \\
\hline
\end{tabular}




\begin{tabular}{|c|c|c|}
\hline Variable & Description & Source \\
\hline Manufacturing & Dummy variable equals 1 if the firm is in the manufacturing industry, and 0 otherwise. & WBES \\
\hline Services & Dummy variable equals 1 if the firm is in the service industry, and 0 otherwise. & WBES \\
\hline Export & Dummy variable equals 1 if the firm exports, and 0 otherwise. & WBES \\
\hline $\begin{array}{l}\text { Number of } \\
\text { Competitors }\end{array}$ & $\begin{array}{l}\text { Regarding your firm's major product line, how many competitors do the firm faces in } \\
\text { its markets? }\end{array}$ & WBES \\
\hline Growth & Growth rate of GDP, averaged over 1995-1999. & $\begin{array}{l}\text { World } \\
\text { Development } \\
\text { Indicators (WDI) }\end{array}$ \\
\hline Inflation & Log difference of consumer price index, averaged over 1995-1999. & $\begin{array}{l}\text { International } \\
\text { Financial } \\
\text { Statistics (IFS) }\end{array}$ \\
\hline Private Credit & Share of claims by financial institutions on the private sector in GDP. & $\begin{array}{l}\text { Beck et al. } \\
(2004)\end{array}$ \\
\hline Anti-Director & $\begin{array}{l}\text { Index of anti-directors rights covering } 6 \text { areas: (1) vote by mail (2) obstacles to the } \\
\text { actual exercise of the right to vote (i.e., the requirement that shares be deposited before } \\
\text { the shareholders' meeting) (3) minority representation on the Board of Directors } \\
\text { through cumulative voting or proportional representation (4) an oppressed minority } \\
\text { mechanism to seek redress in case of expropriation (5) pre-emptive rights to subscribe } \\
\text { to new securities issued by the company (6) right to call a special shareholder meeting. }\end{array}$ & $\begin{array}{l}\text { Djankov et al. } \\
(2008)\end{array}$ \\
\hline Rule of Law & $\begin{array}{l}\text { Index capturing the perceptions of the extent to which agents have confidence in and } \\
\text { abide by the rules of society in } 1998 \text {. }\end{array}$ & $\begin{array}{l}\text { Kaufmann et al. } \\
(2010)\end{array}$ \\
\hline $\begin{array}{l}\text { Financing } \\
\text { Obstacle }\end{array}$ & $\begin{array}{l}\text { How problematic is the general financing an obstacle for the operation and growth of } \\
\text { your business? } 1 \text { for no obstacle, } 2 \text { for minor obstacle, } 3 \text { for moderate obstacle, and } 4 \\
\text { for major obstacle. }\end{array}$ & WBES \\
\hline $\begin{array}{l}\text { General } \\
\text { Corruption }\end{array}$ & $\begin{array}{l}\text { How problematic is the general corruption an obstacle for the operation and growth of } \\
\text { your business? } 1 \text { for no obstacle, } 2 \text { for minor obstacle, } 3 \text { for moderate obstacle, and } 4 \\
\text { for major obstacle. }\end{array}$ & WBES \\
\hline
\end{tabular}




\section{Appendix B}

In an ordered probit model, the dependent variable which is an ordered categorical variable with four categories is assumed to be described by the following equation:

$$
y_{i}=\left\{\begin{array}{ccc}
1 & \text { if } & x_{i}^{\prime} \beta \leq \mu_{1} \\
2 & \text { if } & \mu_{1}<x_{i}^{\prime} \beta \leq \mu_{2} \\
3 & \text { if } & \mu_{2}<x_{i}^{\prime} \beta \leq \mu_{3} \\
4 & \text { if } & \mu_{3}<x_{i}^{\prime} \beta
\end{array}\right.
$$

where $y$ is the dependent variable, $x$ is a vector of control variables, $\beta$ is a vector of coefficients of control variables, $\mu_{1}, \mu_{2}$ and $\mu_{3}$ are the threshold parameters to be estimated together with the coefficients of control variables.

The estimated probabilities of observing each value of the dependent variable are given by the following equations:

$$
\begin{aligned}
& \operatorname{Pr}\left(y_{i}=1 \mid x_{i}, \beta, \mu\right)=\Phi\left(\mu_{1}-x_{i}^{\prime} \beta\right) \\
& \operatorname{Pr}\left(y_{i}=2 \mid x_{i}, \beta, \mu\right)=\Phi\left(\mu_{2}-x_{i}^{\prime} \beta\right)-\Phi\left(\mu_{1}-x_{i}^{\prime} \beta\right) \\
& \operatorname{Pr}\left(y_{i}=3 \mid x_{i}, \beta, \mu\right)=\Phi\left(\mu_{3}-x_{i}^{\prime} \beta\right)-\Phi\left(\mu_{2}-x_{i}^{\prime} \beta\right) \\
& \operatorname{Pr}\left(y_{i}=4 \mid x_{i}, \beta, \mu\right)=1-\Phi\left(\mu_{3}-x_{i}^{\prime} \beta\right)
\end{aligned}
$$

where $\Phi$ is the cumulative standard normal distribution function. It is important to note that the sign of coefficient can be interpreted in the same fashion as that from a linear regression. A positive (negative) coefficient indicates that an increase in the independent variable is associated with an increase (decrease) in the probabilities of observing a high value of the dependent variable. In other words, a positive (negative) coefficient indicates that the independent variable is positively (negatively) related to the dependent variable. 